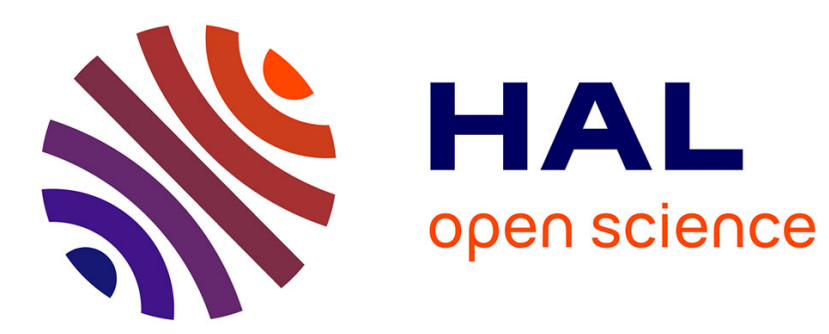

\title{
Study of the Differentiation of Fusarium oxysporum f.sp. albedinis Chlamydospores on Different Culture Media
}

\author{
Smail Abdellaoui, Aicha El Aissami, Omar Benkhemmar, Amina Ouazzani \\ Touhami, Rachid Benkirane, Allal Douira
}

\section{- To cite this version:}

Smail Abdellaoui, Aicha El Aissami, Omar Benkhemmar, Amina Ouazzani Touhami, Rachid Benkirane, et al.. Study of the Differentiation of Fusarium oxysporum f.sp. albedinis Chlamydospores on Different Culture Media. Annual Research \& Review in Biology, 2017, 18 (4), pp.1-9. 10.9734/ARRB/2017/35653 . hal-02136669

\section{HAL Id: hal-02136669 \\ https://hal.science/hal-02136669}

Submitted on 22 May 2019

HAL is a multi-disciplinary open access archive for the deposit and dissemination of scientific research documents, whether they are published or not. The documents may come from teaching and research institutions in France or abroad, or from public or private research centers.
L'archive ouverte pluridisciplinaire HAL, est destinée au dépôt et à la diffusion de documents scientifiques de niveau recherche, publiés ou non, émanant des établissements d'enseignement et de recherche français ou étrangers, des laboratoires publics ou privés. 


\title{
Study of the Differentiation of Fusarium oxysporum f.sp. albedinis Chlamydospores on Different Culture Media
}

\author{
Abdellaoui Smail ${ }^{1,2}$, El Aissami Aicha ${ }^{1}$, Benkhemmar Omar ${ }^{1}$, \\ Amina Ouazzani Touhami ${ }^{2}$, Rachid Benkirane ${ }^{2}$ and Allal Douira ${ }^{2 *}$ \\ ${ }^{1}$ Faculté des Sciences, Université Mohammed V, Laboratoire de Botanique, Mycologie et \\ Environnement, Rabat, Maroc (Morocco). \\ ${ }^{2}$ Faculté des Sciences, Université Ibn Tofail, Laboratoire de Botanique, Biotechnologie et de \\ Protection des Plantes, Kénitra, Maroc (Morocco).
}

Authors' contributions

This work was carried out in collaboration between all authors. All authors read and approved the final manuscript.

Article Information

DOI: $10.9734 / A R R B / 2017 / 35653$

Editor(s):

(1) Iskra Ventseslavova Sainova, Institute of Experimental Morphology, Pathology and Anthropology with Museum to Bulgarian Academy of Sciences (IEMPAM - BAS) in Sofia, Bulgaria. (2) Zeb Saddiqe, Phytochemistry Lab, Department of Botany,Lahore College for Women University,Lahore,Pakistan.

(3) George Perry, Dean and Professor of Biology, University of Texas at San Antonio, USA.

Reviewers:

(1) Hon H. Ho, State University of New York, USA

(2) Tariq Mukhtar, Pir Mehr Ali Shah Arid Agriculture University, Pakistan (3) Muhammad Ishtiaq, Mirpur University of Science \& Technology, Bhimber Campus, Pakistan.

(4) Satya S. Narina, Virginia State University, USA.

(5) Eliton da Silva Vasconcelos, Federal University of São Carlos, Brazil. Complete Peer review History: http://www.sciencedomain.org/review-history/21405

Original Research Article

Received $24^{\text {th }}$ July 2017 Accepted $1^{\text {st }}$ October 2017 Published 14 ${ }^{\text {th }}$ October 2017

\begin{abstract}
Chlamydospores of Fusarium oxysporum f.sp. albedinis are well known as fungus survival spores in soil, also act as a causal agent of Bayoud disease of the date palm. Till now, there are a little study in the literature about the favorable media for the formation of chlamydospores and the stages of chlamydogenesis. This study shows that rice flour based medium (45 chlamydospores per $\mathrm{mm}^{2}$ ), oatmeal (31 chlamydospores per $\mathrm{mm}^{2}$ ) and bean flour $\left(27\right.$ chlamydospores per $\left.\mathrm{mm}^{2}\right)$ tested for the first time, are among the media inducing the formation of chlamydospores in large numbers. The optimum formation of chlamydospores is observed on rice flour-based medium after 7 days of
\end{abstract}


incubation at $18^{\circ} \mathrm{C}$ and $\mathrm{pH} 7$. The effect of light does not seem very important on chlamydogenesis. However, relative humidity has a significant effect on the growth and chlamydogenesis of $F$. oxysporum f.sp. albedinis. The tested $\mathrm{G}_{1}$ isolate grows and forms chlamydospores at relative humidities of 70 and $100 \%$. The number of chlamydospores varies between 40.01 and 44.05 chlamydospores $/ \mathrm{mm}^{2}$. To form chlamydospores, cultures of $F$. oxysporum f.sp. albedinis need to be in contact with the favorable culture medium. Thus, the cultures develop and form more chlamydospores on a single layer of cellophane deposited on a culture medium, but show slower growth and do not form chlamydospores on two layers of cellophane.

Chlamydospores of Fusarium oxysporum f.sp. albedinis are always at the extremity of the mycelial filaments. They differ in one to four cells in superimposed position. A terminal hyphal bulge leads to the formation of the terminal cell. The second cell is formed at the base of the first, and the process continues so that one can sometimes observed chlamydospores in bead-like chains.

Keywords: Fusarium oxysporum f.sp. albedinis; chlamydospores; culture media; chlamydogenesis; $\mathrm{pH}$; temperatures; relative humidity.

\section{INTRODUCTION}

For more than 100 years, the palm groves of Morocco and Algeria have been devastated by a tellurium fungus, Fusarium oxysporum f.sp. albedinis, which causes rapid decline of the date palm [1]. This vascular fusariosis, commonly called Bayoud, has decimated most commercial varieties [2].

F. oxysporum f.sp. albedinis produces three types of asexual spores $[3,4]$. These are microconidia with variable size $(3-15 \times 3-5 \mu \mathrm{m})$ and are often uni-cellular, sometimes bi-cellular, and rarely have two partitions [5]. Macro-conidia measuring 20-35 x 3-5 $\mu \mathrm{m}$ with pointed and short extremity. On cultures, in soil or on infected palm fragments, even in the absence of its host, the fungus produces elements of resistance which are chlamydospores either from the macroconidia or from the mycelial cells which can be found isolated or in pairs, rarely in chains [6].

Many authors have given a detailed description of the macroscopic and microscopic characteristics of life cycle components of $F$. oxysporum f.sp. albedinis $[7,8,9]$. But, there was study neither on favorable culture media for the formation of chlamydospores nor the process of chlamydogenesis.

In this study, different culture media were tested to determine the most favorable medium for the formation of chlamydospores of $F$. oxysporum f.sp. albedinis, forms of fungus survival in soil and on plant debris. In addition, the steps of formation of these chlamydospores were also studied.

\section{MATERIALS AND METHODS}

\subsection{Isolation of Fusarium oxysporum f.sp. albedinis}

The fungus can be easily isolated from date palm roots exhibiting typical symptoms of Fusarium wilt [10]. Seven isolates of $F$. oxysporum f.sp. albedinis were isolated from the roots of the date palm from the Ziz valley in Errachidia (Isolates: $64,42,51,124,93$, and 97) and a single G1 isolate from the Goulmima region in southeastern Morocco.

The roots were disinfected with alcohol and then dried on sterile filter paper before being deposited on PSA medium (Potato-SaccharoseAgar: $200 \mathrm{~g}$ of potato; $20 \mathrm{~g}$ saccharose; $15 \mathrm{~g}$ agar; $1000 \mathrm{~mL}$ distilled water). The cultures obtained after incubation for seven days at $28^{\circ} \mathrm{C}$ were purified by successive subcultures and preserved for subsequent studies.

\subsection{Influence of Culture Ingredients on the Formation of Chlamydospores}

Various culture media were tested: PSA medium rice flour medium (14 g rice flour; $4 \mathrm{~g}$ yeast extract; $15 \mathrm{~g}$ agar; $1000 \mathrm{~mL}$ distilled water), bean flour medium (14 $\mathrm{g}$ of bean flour, $4 \mathrm{~g}$ of yeast extract, $15 \mathrm{~g}$ of agar, $1000 \mathrm{~mL}$ of distilled water), oatmeal medium (14 g oatmeal, $4 \mathrm{~g}$ yeast extract, $15 \mathrm{~g}$ agar, $1000 \mathrm{ml}$ distilled water), gypsum-based medium ( $14 \mathrm{~g}$ plaster, $4 \mathrm{~g}$ yeast extract, $15 \mathrm{~g}$ agar, $1000 \mathrm{ml}$ distilled water) and celery juice medium (200 g celery, $20 \mathrm{~g}$ sucrose, $15 \mathrm{~g}$ agar: $1000 \mathrm{~mL}$ distilled water: $1000 \mathrm{~mL})$. 
For each culture medium, three Petri dishes were seeded with an explant of $5 \mathrm{~mm}$ diameter, taken at the margin of a young culture of seven days. After seven days of incubation in the dark and at $28^{\circ} \mathrm{C}$., sporulation was evaluated by taking five 5 $\mathrm{mm}$ diameter discs. These discs were put into a test tube containing $1 \mathrm{~mL}$ of tap water and agitated with a vortex to get free chlamydospores.

About $0.1 \mathrm{ml}$ of the suspension was mounted on a glass slide and the number of spores was counted with respect to the microscopic field. Only culture media that promoted the production of a large number of chlamydospores was maintained for further testing.

\subsection{Influence of Rice Flour-based Medium on the Induction of Chlamydospores in Different Isolates of Fusarium oxysporum f.sp. albedinis}

Six isolates of $F$. oxysporum f.sp. albedinis collected from the roots of the date palm from the Ziz Valley and a single isolate from the Goulmima region were tested on rice flour based medium (14 g rice flour; $4 \mathrm{~g}$ yeast extract; $15 \mathrm{~g}$ agar; $1000 \mathrm{~mL}$ distilled water).

Three Petri dishes were seeded with an explant of $5 \mathrm{~mm}$ diameter taken at the margin of a seven days young old culture on the PSA medium. The dishes were incubated 24-hours in the dark at 28 C. Three repetitions were performed for each case. Only isolates that produced a large number of chlamydospores would be maintained for further testing.

\subsection{Influence of the Succession of Two Culture Media (PSA and Rice Flour) in the Same Petri Dish}

In a sterile Petri dish, two culture media were prepared in two concentric rings separated by two sterile cylindrical cardboards lined with waterproof membrane to isolate the culture media. The first smaller ring was filled with rice flour by carefully incorporating under sterile conditions a cylinder which delimited the inner core. Once the medium had solidified, a second wider cylinder was introduced and the space between the first and the second cylinders was filled with PSA medium. At the end, the space between the second cylinder and the Petri dish was filled again with the medium made from rice flour (Fig. 1).

A cut disc of the mycelium, taken from a young culture of the fungus (isolate $\mathrm{G} 1$ ), developed on the usual PSA medium, was transplanted in the center of this Petri dish containing different culture media in concentric rings.

\subsection{Influence of Some Physico-chemical Factors on the Formation of Chlamydospores}

\subsubsection{Effect of $\mathrm{pH}$ and temperature on chlamydogenesis}

A pH range $(4,5,7,9$, and 12) was obtained by adding $\mathrm{HCl}$ or $\mathrm{NaOH}$ [1N] to the rice flour medium. The $\mathrm{pH}$ was adjusted before autoclaving. Similarly, a temperature range $\left(5^{\circ} \mathrm{C}\right.$., $18^{\circ} \mathrm{C}$. $37^{\circ} \mathrm{C} ., 44^{\circ} \mathrm{C}$.) was studied on a medium based on Rice flour. Three replicates were performed. The Petri dishes were seeded and incubated in the same manner as previously.

\subsubsection{Effect of light on chlamydogenesis}

Petri dishes containing the rice flour medium were seeded by mycelial discs of a young culture of $F$. oxysporum f.sp. albedinis developed on PSA. Three dishes were incubated in the dark and three others exposed to light. Three replicates were performed.

\subsubsection{Effect of relative humidity on chlamydogenesis}

To assess the effect of relative humidity $(\mathrm{RH})$ on chlamydogenesis, we used the technique of Wash-burn (1982). This technique consists of the use a mixture of distilled water and glycerine at different $\mathrm{RH}$ values:

\footnotetext{
For $\mathrm{RH}=0$ (100\% glycerine);

For $\mathrm{RH}=30(30 \%$ distilled water and $70 \%$ glycerin);

For $\mathrm{RH}=50 \quad(50 \%$ distilled water and $50 \%$ glycerin);

For $\mathrm{RH}=70 \quad(70 \%$ distilled water and $30 \%$ glycerin);

For $\mathrm{RH}=100$ (100\% distilled water);
}

$10 \mathrm{~mL}$ of these solutions were distributed in Petri dishes. 


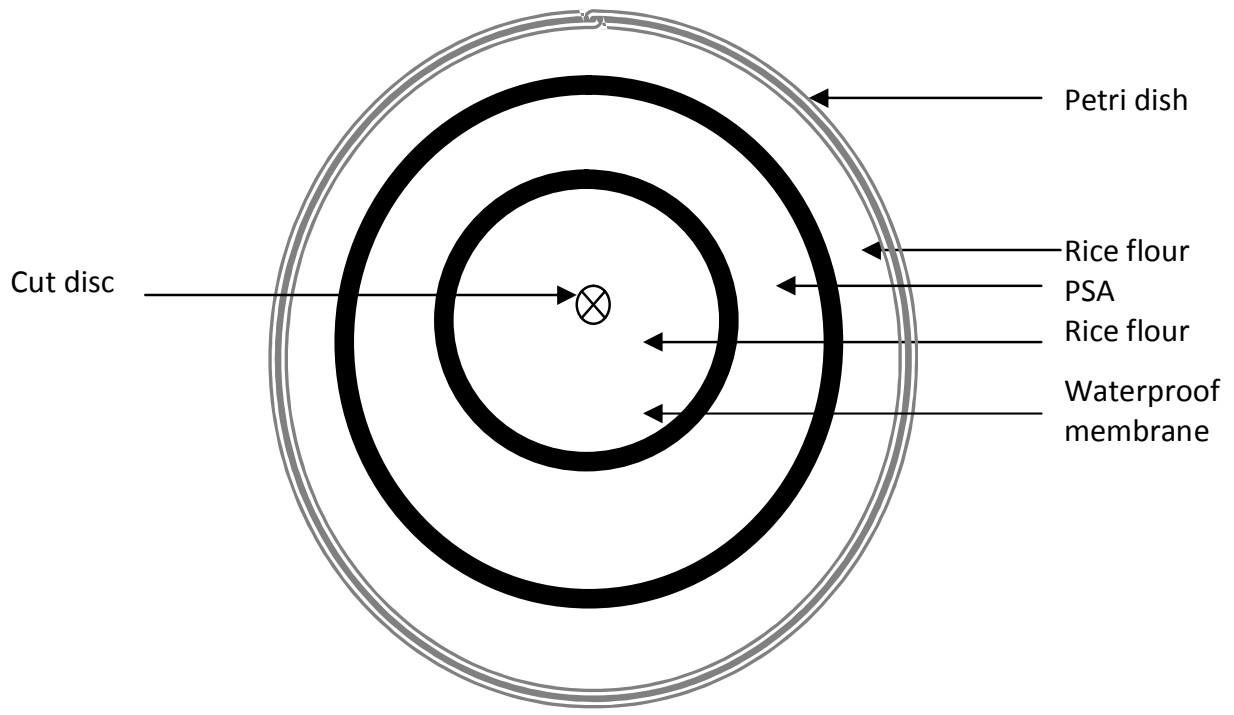

Fig. 1. Diagram of a petri dish containing two concentric culture media

Sterile slides, bearing a layer of rice flour medium (one layer per slide), were inoculated by cuttings of a young culture of $F$. oxysporum f.sp. albedinis taken from a PSA plate. These slides were then placed on sterile beads in sterile Petri dishes. Three replicates were made for each $\mathrm{RH}$.

\subsubsection{Formation of chlamydospores on cellophane membrane}

The nature of the substances inducing the formation of chlamydospores was demonstrated by the technique of cellophane [11,12]. Three Petri dishes containing the rice flour culture media were covered with a layer of sterile cellophane, and three other dishes containing the same culture medium were covered with two sterile layers of cellophanes. Discs of $5 \mathrm{~mm}$ in diameter from a 7-day old culture of Fusarium, were placed in the center of the surface of the cellophane. The dishes were incubated for 24hours. At the end of this time, the adhering mycelium was removed and analyzed under an optical microscope.

\subsubsection{Effect of heat shock on germination of chlamydospores}

Each of the Test tubes contains $1 \mathrm{~mL}$ of the suspension of chlamydospores from $F$. oxysporum f.sp. albedinis were exposed for one hour at temperatures of $5^{\circ} \mathrm{C}, 40^{\circ} \mathrm{C}, 50^{\circ} \mathrm{C}, 56^{\circ} \mathrm{C}$, and $60^{\circ} \mathrm{C}$. For each temperature, one drop of the suspension was spread on Petri dishes containing the PSA medium. The dishes were incubated seven days in the dark and at $28^{\circ} \mathrm{C}$.

\subsection{The Stages of Chlamydogenesis}

Three $5 \mathrm{~mm}$ diameter discs from a seven-day old culture on Rice flour medium were placed in a test tube containing $1 \mathrm{ml}$ of tap water and one drop of cotton blue, The mixture was milled and then vortexed. A $0.1 \mathrm{~mL}$ drop of the suspension was placed between the slide and the cover slip.

\section{RESULTS AND DISCUSSION}

On rice flour, only isolates $\mathrm{G} 1$ and Isolate 64 from $F$. oxysporum f.sp. albedinis formed chlamydospores, with 46 and 2 chlamydospores $/ \mathrm{mm}^{2}$ respectively. The G1 isolate was also able to form chlamydospores on oatmeal, bean and celery media.

The rice flour medium, most favorable for the formation of chlamydospores, was used [13] to induce the rapid formation of chlamydospores in certain pathogenic yeasts, e.g. Candida albicans.

The celery medium did not allow the formation of chlamydospores, contradictory to that reported previously by Huang [14]. This author studied the effect of plant extracts on the induction of chlamydospores in Fusarium oxysporum and other species of the Fusarium genus and noted that the celery-based medium was the most favorable for chlamydospore formation. 


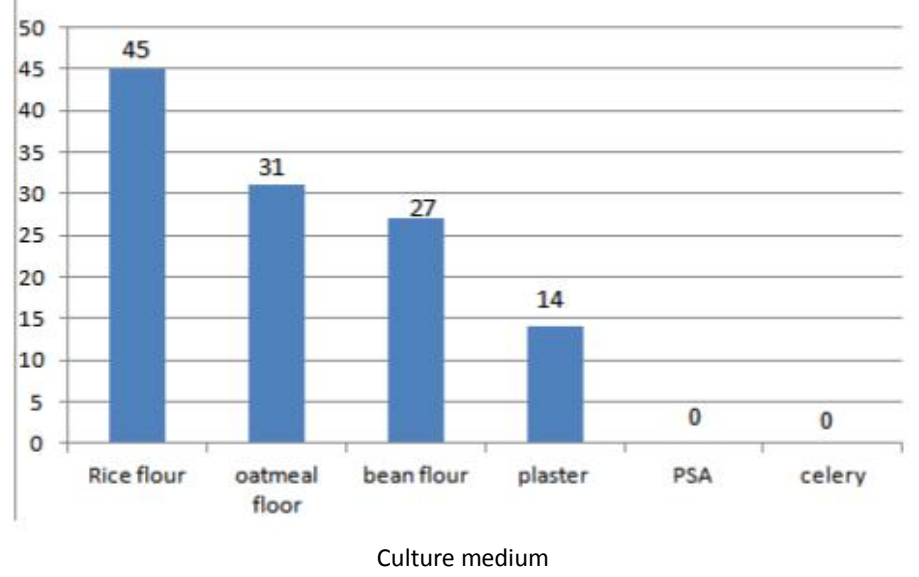

Fig. 2. Number of chlamydospores, by microscopic field, formed by the $\mathbf{G 1}$ solate of $F$. oxysporum $\mathrm{f}$ sp. albedinis on different culture media

In Fusarium solani, the formation of chlamydospores was observed after incubation of the cultures on PDA at $25^{\circ} \mathrm{C}$. for 10 days or, according to the method of Smith and Snyder [15], after an external supply of carbon and nitrogen [16] or after addition of glucose to a solution of the soil [17]. Carbon sources, mainly citrate, and a $\mathrm{pH}$ ranging from 5.2 to 6 also promote the production of chlamydospores [18]. Other authors have reported that some herbicides stimulate the formation of chlamydospores in $F$. oxysporum, as in the case of glyophosate, at a concentration of $1.5 \mathrm{mM}$ [19]. Ciotola et al. [20] noted that the extract of fertilized straw of Striga hermonthica induces the formation of chlamydospores by mass in $F$. oxysporum after incubation of the cultures for 21 days at $21^{\circ} \mathrm{C}$. or 14 days at $30^{\circ} \mathrm{C}$. Similarly, strains of Phytophthora palmivora (K and 1) were able to form a large number of chlamydospores on oatmeal medium and much less on pea media, coconut milk, and synthetic media supplemented with amino acids [21]. Chlamydospores were observed on the media well before the depletion of the reserves, implying that elements of these media induce their formation. In Cryptococcus neoformans, responsible for meningoencephalitis in humans, the formation of chlamydospores was closely associated with the production of aflatoxins [22].

Xiaorong and Heitman [23] noted that the formation of chlamydospores in most fungi depends on environmental conditions, darkness and temperature [24], and the plant protection products used [25]. The formation of these resistant structures in $C$. neoformans is favored by incubation for 14 days at $22^{\circ} \mathrm{C}$. and also in the darkness of the cultures developing on $V_{8}$ medium [26,27].

Daniel et al. [28] showed that the incubation of Trichoderma spp for 14 days on LNA-based medium favors the production of chlamydospores whereas in Trichoderma harzianum SH2303 the Gorodkowa medium culture $(\mathrm{C}: \mathrm{N}=1: 2)$ induces the formation of these chlamydospores [29]. Other authors have reported that the formation of chlamydospores in Aspergillus flavus has been induced by secondary metabolites of Ralstonia solanacearum [30].

Alicia et al. [31] reported that cultures of some strains of C. albicans, incubated at $28^{\circ} \mathrm{C}$, sporulated and formed chlamydospores in a shorter time (16 hours) on CMB synthetic medium (cornmeal broth) supplemented with $5 \%$ of milk, while Bennet et al. [32] reported that the production of chlamydospores in $F$. oxysporum f.sp. vasinfectum is rapid on supersol broth medium without glucose.

The succession of culture media within the same Petri dish influences the formation of chlamydospores in F. oxysporum f.sp. albedinis (Fig. 3). Indeed, after incubation for seven days in the dark, the fungus growing on the centre of rice flour medium plate formed chlamydospores. On the other hand, the fungus on PSA medium, did not form these structures but when the mycelia reached the edge of the dishes containing the rice flour medium chlamydospores were produced. 


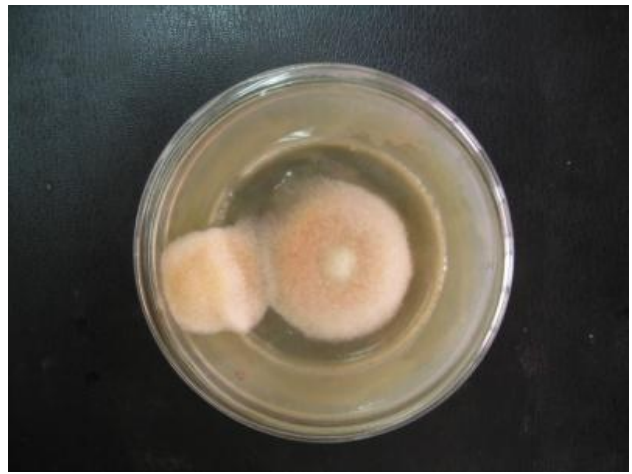

Fig. 3. Petri dish containing two culture media: rice flour based medium (center and periphery) and PSA based media (between two media)

The $\mathrm{pH}$ and temperatures also influenced chlamydogenesis in F. oxysporum f .sp.albedinis. In acid medium, cultures growth was almost null and chlamydospores did not form. In a neutral medium ( $\mathrm{pH}$ in the order of 7$)$, the mycelial growth was maximum and the optimum rate of the chlamydogenesis was observed (Table 1), i.e., 49 chlamydospores per $\mathrm{mm}^{2}$. Similarly, Alicia et al. [31] and Nobil et al. [33] reported that the formation of chlamydospores in C. albicans is highly dependent on the $\mathrm{pH}$ of the culture medium. When the medium is basic, mycelial growth (MG) is much greater $(6$ and $7 \mathrm{~cm})$ than that observed in a neutral medium $(4 \mathrm{~cm})$, but the chlamydogenesis is low at $\mathrm{pH} 9$ and becomes null at $\mathrm{pH} 12$.

Table 1. Effect of pH on chlamydogenesis of F. oxysporum $f$.sp. albedinisa

\begin{tabular}{|c|c|c|}
\hline $\mathrm{pH}$ & MG (cm) & N Chlamy \\
\hline 4 & $0^{d}$ & $0^{\mathrm{b}}$ \\
\hline 5 & $0^{\mathrm{d}}$ & $0^{\mathrm{b}}$ \\
\hline 7 & $4.03^{\mathrm{c}}$ & $49^{a}$ \\
\hline 9 & $6.06^{b}$ & $8.7^{\mathrm{b}}$ \\
\hline 12 & $7.13^{\mathrm{a}}$ & $0^{\mathrm{b}}$ \\
\hline
\end{tabular}

For a given column, the values followed by the same letter do not differ significantly at the $5 \%$.

The maximum rate of the chlamydospores formation is observed on rice flour-based medium after 7 days of incubation at $18^{\circ} \mathrm{C}$. in the studied isolate (Table 2). Above $37^{\circ} \mathrm{C}$, fungus showed very slight growth and chlamydospores were absent. Bulit et al. [34] reported that the optimum temperature for growth of $F$. oxysporum f. sp. albedinis (Foa) is between $27^{\circ}$ and $28^{\circ} \mathrm{C}$ and mycelial growth is inhibited at around $38^{\circ} \mathrm{C}$.

Table 2. Influence of the temperature on the chlamydogenesis of Fusarium oxysporum $\mathrm{f}$. sp. Albedinis

\begin{tabular}{lll}
\hline Temperature & MG & N chlamy \\
\hline $5^{\circ}$ & $4.73^{\mathrm{b}}$ & $12.31^{\mathrm{b}}$ \\
$18^{\circ}$ & $7.23^{\mathrm{a}}$ & $21^{\mathrm{a}}$ \\
$37^{\circ}$ & $1.76^{\mathrm{c}}$ & $0^{\mathrm{c}}$ \\
$44^{\circ}$ & $0^{\mathrm{d}}$ & $0^{\mathrm{C}}$ \\
\hline \multicolumn{3}{c}{ MG: Mycelial growth; $\mathrm{N}$ chlamy: number of } \\
\multicolumn{3}{r}{ chlamydospores per mm m. $^{2}$}
\end{tabular}

For a given column, the values followed by the same letter do not differ significantly at the $5 \%$.

The effect of light does not seem to be very important on the chlamydogenesis of $F$. oxysporum f.sp. albedinis. The incubation in darkness or under light of cultures of the tested isolate did not induce a distinctive effect on growth or on the formation and number of chlamydospores. In 1975, Bounaga noted that the mycelial growth of $F$. oxysporum f.sp. albedinis and the number of chlamydospores formed were unaffected by the light parameter [35]. However, relative humidity has a significant effect on the growth and chlamydogenesis of $F$. oxysporum f.sp. albedinis (Table 3). The tested isolate grew and formed chlamydospores at relative humidity of $70 \%$ and $100 \%$ respectively, the number of chlamydospores varied between 40.01 and 44.05 chlamydospores $/ \mathrm{mm}^{2}$, respectively. For values of 0 to $30 \%$ relative humidity, mycelial growth remained lower than that observed in culture of the incubated isolate at $70 \%$ and $100 \%$, and the number of formed chlamydospores was lower (11.35 and 17 chlamydospores $/ \mathrm{mm}^{2}$ ).

Table 3. Effect of light on the chlamydogenesis of $F$. oxysporum f.sp. albedinis

\begin{tabular}{lll}
\hline Light & MG & N chlamy \\
\hline Obscurity & $7.38^{\mathrm{a}}$ & $46^{\mathrm{a}}$ \\
Light & $7.5^{\mathrm{a}}$ & $44.26 \mathrm{a}$ \\
\hline \multicolumn{2}{c}{ MG: Mycelial } & Growth; N Chlamy: Number of \\
& chlamydospores
\end{tabular}



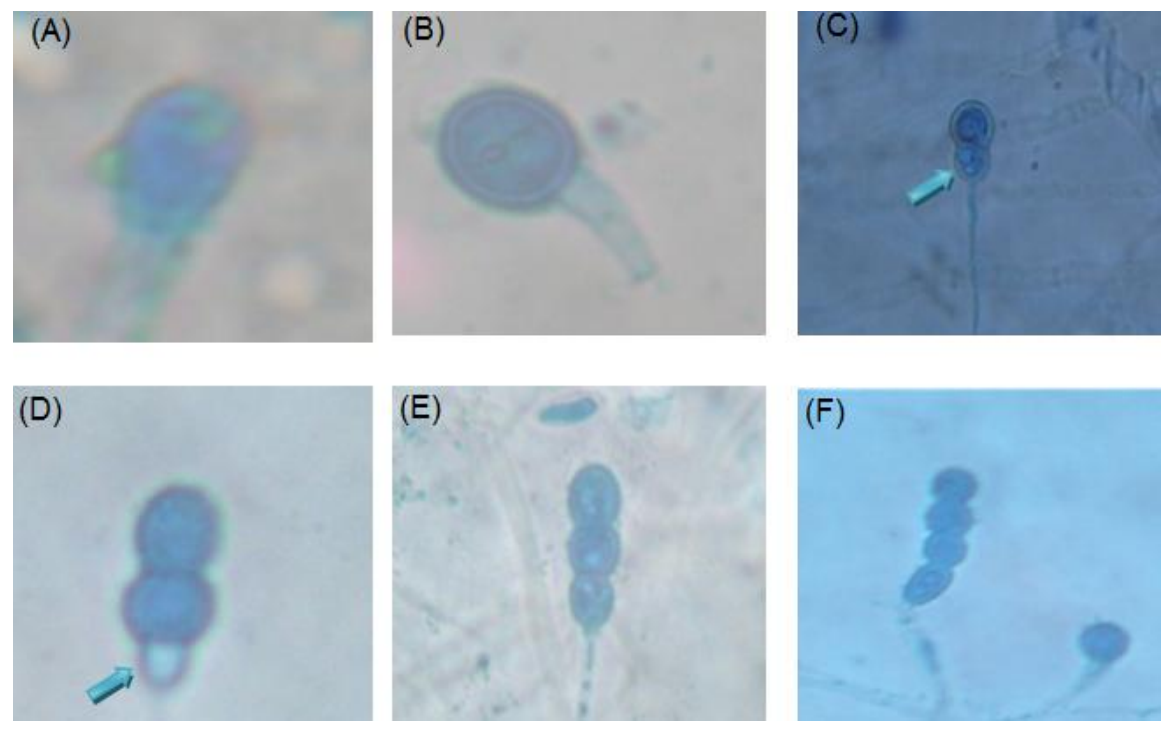

Fig. 4. The steps of the chlamydogenesis differentiation: (A): Bulge of the hyphal extremity and appearance of the first terminal cell, (B): Hardening of the terminal cell, (C): Formation of the second cell, (D): Formation of the third cell, (E) and (F): Beads of three or four terminal cells

For a given column, the values followed by the same letter do not differ significantly at the $5 \%$.

Table 4. Effect of relative humidity on

Fusarium oxysporum f. sp. albedinis chlamydogenesis

\begin{tabular}{lll}
\hline \%RH & MG & N chlamy \\
\hline 0 & $3.6^{\mathrm{c}}$ & $11.35^{\mathrm{d}}$ \\
30 & $4.14^{\mathrm{c}}$ & $17^{\mathrm{c}}$ \\
50 & $5.14^{\mathrm{b}}$ & $21.54^{\mathrm{b}}$ \\
70 & $7.48^{\mathrm{a}}$ & $40.01^{\mathrm{a}}$ \\
100 & $7.58^{\mathrm{a}}$ & $44.05^{\mathrm{a}}$ \\
\hline
\end{tabular}

For a given column, the values followed by the same letter do not differ significantly at the $5 \%$.

The culture of the isolate of tested $F$. oxysporum $f$.sp. albedinis which developed on a single layer of cellophane deposited on culture medium showed greater mycelial growth and form chlamydospores. However, cultures growing on two slices of cellophane showed slow growth and did not form chlamydospores.

According to Dennis and Webster [12], and Berber et al. [11], certain substances of the culture medium were necessary for the induction of chlamydospores. The use of a single layer of cellophane allows the diffusion of these substances, but two layers of cellophane make it a barrier to this diffusion. The cellophane technique made it possible to isolate the chlamydospores and to test their germinative ability after a thermal shock. These resistant structures retained their germinating power after a one-hour heat shock in the range of $\left[5^{\circ} \mathrm{C}\right.$., $50^{\circ} \mathrm{C}$.]. Beyond $50^{\circ} \mathrm{C}$, chlamydospores lost their germinative power (Table 2). Bounaga [35] reported that the chlamydospores of $F$. oxysporum f.sp. albedinis lose their germination capacity at a temperature of $60^{\circ} \mathrm{C}$.

\section{CONCLUSION}

The in vitro formation of chlamydospores of $F$. oxysporum f.sp. albedinis varies depending on the tested media culture, the incubation temperature and the $\mathrm{pH}$ of the medium. The rice flour-based culture medium is the most favorable for chlamydogenesis; it far exceeds the effect of the media based on flour of Avoine, beans and the one based on plaster. The optimum production of chlamydospores is observed in the G1 culture growing on rice flour medium, after 7 days of incubation, at $18^{\circ} \mathrm{C}$. and $\mathrm{pH} 7$. Under these conditions, the number of chlamydospores is important for relative humidities of 70 and $100 \%$. The current study provided new information concerning their differentiation on the stages of chlamydogenesis in F. oxysporum f.sp. albedinis. 


\section{COMPETING INTERESTS}

Authors have declared that no competing interests exist.

\section{REFERENCES}

1. Killan C, Maire R. Le Bayoud, maladie du dattier. Bulletin de la Société d'histoire naturelle d'Afrique. 1930;21:89-101.

2. Djerbi M. Bayoud disease in North Africa: history distribution, diagnosis and control. Date Palm Journal. 1982;1:153-197.

3. Malençon G. Le Bayoud, maladie fusarienne du palmier dattier au Maroc. Fruits. 1934;5:279-289.

4. Pereau-leroy P. Le palmier dattier au Maroc. Ministère de l'agriculture. Institut Français de Recherche Outre-mer, Paris. 1958;142.

5. Sghir F, Touati J, Mouria B, Ouazzani Touhami A, Filali-Maltouf A, El Modafar C, Moukhli A, Benkirane R, Douira A. Variation in pathogenicity of Fusarium oxysporum f. sp. albedinis on two cultures associated with date palm of Moroccan oasis. World Journal of Pharmaceutical and Life Sciences. 2016;2(3):56-68.

6. Louvet J. Observations sur la localisation des chlamydospores de Fusarium oxysporum dans les tissus des plantes parasitées. Travaux Dédiés à G. Viennot Bourgin, pp. 193-197. INRA, Paris, France. 1977;193-197.

7. Chettab N, Dubost D, Kada A. Remarques sur l'identification du Fusarium oxysporum f.sp. albedinis, agent de la fusariose vasculaire du palmier dattier (Bayoud). Bulletin d'Agronomie Saharienne. 1978;1: 38-53.

8. Sedra MH, Djerbi M. Fusarium oxysporum causing the vascular wilt disease of palm (Bayoud) and Canary Island palm. In: Proceedings of the Second Symposium on the Palm Date, Saudi Arabia. 1986;359365.

9. Djerbi M, Sedra MH, El Idrissi Ammari MA. Cultivation characteristics and identification of Fusarium oxysporum f.sp. albedinis: Causal agent of Bayoud. Annals of the National Institute of Agronomic Research of Tunisia. 1985;58:1-8.

10. Louvet J, Toutain G. Research on Fusarium diseases. VIII. New observations on date palm blight and precise control. Annals of Phytopathology. 1973;5:35-52.
11. Berber F, Ouazzani Touhami A, Badoc A, Douira A. Antagonisme in vitro et in vivo de deux Trichoderma à l'égard de quatre espèces de Bipolaris pathogènes sur le Sorgho. Bulletin de la Société de Pharmacie de Bordeaux. 2009;148:93114.

12. Dennis C, Webster J. Antagonistic properties of Trichoderma species groups: I. Production of non-volatile antibiotics. Transactions of the British Mycological Society. 1971;57(1):25-39.

13. Jansons VK, Nickerson WJ. Chemical composition of chlamydospores of Candida albicans. Journal of Bacteriology. 1970;104(2):922-932.

14. Huang JW, Sun SK, Ko WH. A medium for chlamydospore formation in Fusarium. Annals of the Phytopathological Society of Japan. 1983;49:704-708.

15. Smith SN, Snyder WC. Germination of Fusarium oxysporum chlamydospores in soils favourable and unfavourable to wilt establishment. Phytopathology. 1972;62: 273-277.

16. Smolińska U, Kowalczyk W. The impact of the Brassicaceae on the population of Fusarium solani (Mart.) Sacc. and Fusarium oxysporum Schlecht. Journal of Horticultural Research. 2014;22(1):123129.

17. Goyal JP, Maraite H, Meyer JA. Abundant production of chlamydospores by Fusarium oxysporum f. sp. melonis in soil extract with glucose. Netherlands Journal of Plant Pathology.1973;79:162-164.

18. Griffin GJ. Roles of low $\mathrm{pH}$, carbon and inorganic nitrogen source use in chlamydospore formation by Fusarium solani. Revue Canadienne de Microbiologie. 1976;22(9):1381-1389.

19. Azouaoui Ait Kettout T, Boucenna B, Amgoud M, Rahmania FB. Essai de lutte in vitro par le glyphosate contre des champignons telluriques phytopathogènes: Fusarium et Pythium. Sciences \& Technologie. 2017;26:75-80.

20. Ciotola M, Di Tommaso A, Watson AK. Chlamydospore production, inoculation methods and pathogenicity of Fusarium oxysporum M12-4A, a biocontrol for Striga hermonthica. Biocontrol Science and Technology. 2010;10(2):129-145.

21. Riou S, Ravisé A. Etude des chlamydospores chez quelques espèces de Phytophthora de Bary. Cahiers de la Maboké. 1970;8(2):93-106. 
22. Abou-Gabal M, Fagerland J. Ultra structure of the chlamydospore growth phase of Aspergillus parasiticus associated with higher production of aflatoxins. Mykosen. 1981;24:307-311.

23. Xiaorong L, Heitman J. Chlamydospore formation during hyphal growth in Cryptococcus neoformans. Eukaryotic Cell. 2005;4(10):1746-1754.

24. Ohara T, Tsuge T. FoSTUA, encoding a basic helix-loop-helix protein, differentially regulates development of three kinds of asexual spores, macroconidia, microconidia, and chlamydospores, in the fungal plant pathogen Fusarium oxysporum. Eukaryotic Cell. 2004;3:14121422.

25. Cole GT, Seshan KR, Phaneuf M, Lynn KT. Chlamydospore-like cells of Candida albicans in the gastrointestinal tract of infected, immunocompromised mice. Canadian Journal of Microbiology. 1991; 37(8):637-646.

26. Regulez P, Ponton J, Dominguez JB, Goni FM, Uruburu F. Lipid composition and the transition from yeast-like to chlamydospore cells of Pullularia pullulans. Canadian Journal of Microbiology. 1980;26:14281437.

27. Kono $\mathrm{Y}$, Yamamoto $\mathrm{H}$, Takeuchi $\mathrm{M}$, Komada $\mathrm{H}$. Alterations in superoxide dismutase and catalase in Fusarium oxysporum during starvation- induced differentiation. Biochimica and Biophysica Acta. 1995;1268(1):35-40

28. Daniel C Burcham, Jia Yih Wong, Nelson $\checkmark$ Abarrientos Jr, Mohamed Ismail Mohamed Ali, Yok King Fong, Francis WMR Schwarze. In vitro evaluation of antagonism by Trichoderma spp. towards Phellinus noxius associated with rain 3 tree (Samanea saman) and Senegal mahogany (Khaya senegalensis) in Singapore. BioRxiv. 2017;24.

29. Li YQ, Song K, Li YC, Chen J. Statistical culture-based strategies to enhance chlamydospore production by Trichoderma harzianum SH2303 in liquid fermentation. Journal of Zhejiang University Science B. 2016;17(8):619-27.

30. Spraker JE, Sanchez LM, Lowe TM, Dorrestein PC, Keller NP. Ralstonia solanacearum lipopeptide induces chlamydospore development in fungi and facilitates bacterial entry into fungal tissues. Multidisciplinary Journal of Microbial Ecology. 2016;10(9):2317-2330.

31. Alicia ZS, Blanca OS, Mariana GH, Magdalena CC, Alexandro B. Rapid Production of Candida albicans chlamydospores in liquid media under various incubation conditions. Nihon Ishinkin Gakkai Zasshi. 2006;47(3):231234.

32. Bennett RS. Davis RM. Method for rapid production of Fusarium oxysporum f. sp. vasinfectum chlamydospores. Journal of Cotton Science. 2013;17:52-59.

33. Nobil CJ, Bruno VM, Richard ML, Davis DA, Mitchell AP. Genetic control of chlamydospore formation in Candida albicans. Microbiology. 2003;149(12): 3629-3637.

34. Bulit J, Bouhot D, Louvet J, Toutai G. Recherches sur les fusarioses 1. Travaux sur le bayoud, fusariose vasculaire du palmier dattier en Afrique du Nord. Annals des Epiphyties. 1967;18:213-239.

35. Bounaga N. Germination de microconidies et macroconidies de Fusarium oxysporum f.sp. albedinis. Bulletin de la Société d'Histoire Naturelle d'Afrique du Nord. 1975;66:39-44.

(c) 2017 Smail et al.; This is an Open Access article distributed under the terms of the Creative Commons Attribution License (http://creativecommons.org/licenses/by/4.0), which permits unrestricted use, distribution, and reproduction in any medium, provided the original work is properly cited.

Peer-review history:

The peer review history for this paper can be accessed here: http://sciencedomain.org/review-history/21405 